\title{
Prevalence of Periodontal Disease in a Group of Egyptian Children with Diabetes Mellitus Type 1
}

\author{
NERMEEN M.F. HAIDER, M.D.*; NOURHAN ABD EL WAHAB EL-DOKKI, Ph.D.** and \\ DALIA M. MOHEB, Ph.D.** \\ The Department of Pediatrics, National Institute for Diabetes and Endocrinology* and \\ The Department of Pediatric Dentistry and Dental Public Health, Faculty of Oral and Dental Medicine, Cairo University**
}

\begin{abstract}
Background: Diabetes Mellitus (DM) is a serious metabolic syndrome with its two basic types resulting in abnormal fat, carbohydrate, and protein metabolism. Periodontal disease is considered as the sixth leading complication for individuals suffering from diabetes mellitus. Periodontal disease can be initiated, developed and progressed because of metabolic imbalances in the tissues which lower the diabetic patients resistance of diabetics to infection.

Aim of Study: The aim of this study was tostudy periodontal disease experience in a group of diabetic children and the unmet treatment needs. 3 to 12 years old suffering from type 1 diabetes mellitus.

Material and Methods: 91children with type 1 diabetes mellites, their ages range from 3 to 12 participated in the study with the mean time since the onset of diabetes was $5.41 \pm 3.13$ years in boys and $4.88 \pm 2.29$ years in girls.

Results: There was a significant differencecorrelation between $\mathrm{HbA}_{1 \mathrm{c}}$ and periodontitis and diabetic ketoacidosis attacks.

Conclusion: Elevated blood glucose levels in patients with diabetes mellitus patients is prominently associated with periodontal disease in the form of periodontitis and xerostomia leading to high risk of ketoacidosis attacks.
\end{abstract}

Key Words: Diabetes mellites - HBA $1{ }_{1}$ - PeriodontitisXerostomia - Ketoacidosis attacks.

Significant statement: This study confirmed that the diabetic patients who suffered from uncontrolled diabetes mellitus and elevated levels of $\mathrm{HbA}_{1 \mathrm{c}}$ showed significantperiodontal diseaseand ketoacidosis attacks.

\section{Introduction}

DIABETES mellitus is the term used to identify a group of disorders characterized by elevated blood glucose to eitherinsulin secretion deficiency

Correspondence to: Dr. Nermeen M.F. Haider, E-Mail: Dr.nermeenhaider@hotmail.com or increased cellular resistance to the actions of insulin, resulting in many metabolic abnormalities affecting carbohydrates, fats and proteins [1].

Hyperglycemia has many marked symptoms including polyuria, polydipsia, weight loss, sometimes with polyphagia, and blurred vision, growth impairment and certain infections susceptibility may also be accompanied with chronic hyperglycemia. Hyperglycemia with ketoacidosis are considered acute life-threatening consequences of diabetes [2]

Diabetes mellitus can be associated with a number of oral disorders such as periodontal diseases gingivitis, periodontitis,salivary dysfunction, oral mucosal diseases, as well as, oral infections such as candidiasis, taste disturbance and many other neurosensory disorders [3].

Although there is lack of information about the correlation between diabetes mellitus and dental caries [4], it is generally accepted that diabetic patients are at high risk to very early periodontal destruction [5] and also gingival inflammation [6]

Periodontal disease is can be associated with diabetes mellitus due to poor metabolic control making diabetes a disorder of great importance to both dentists and dental hygienists as well as to patients seen in the dental office [7].

\section{Material and Methods}

This study was carried out in the out patient diabetic clinic at El-Demerdash Hospital, Ain Shams University and the National Institute of Diabetes from March 201410 March 2015.

On 91 children aged from 3 to 12 years old suffering from type 1 diabetes mellitus. 


\section{Inclusion criteria:}

Only controlled diabetic children,with type 1 diabetes mellitus.

\section{Exclusion criteria:}

Diabetic children with other chronic complications or other systemic diseases or patients undergoing active orthodontic treatment. Written informed consent was obtained from parents of each patient. Age, sex and duration of diabetes were recorded.

The subjects voluntarily agreed to participate in the study after the study's purpose and methods were explained.

All children included in this study were subjected to the following:

\section{Data collection:}

Data were collected by means of an open ended questionnaire covering patient records of weight and glycatedhemoglobin $\mathrm{HbA}_{1 \mathrm{C}}$ for all the study participants.

\section{Methods of examination:}

Clinical examination was carried to assess diabetic children caries experience. Examination was carried out under natural day light while the child sitting on an ordinary chair, teeth were cleaned first by cotton pellet and gauze pads then teeth were examined with the help of disposable diagnostic set (mirror, probe and napkin).

\section{Infection control measures:}

- Hand washing: Routine hand washing was performed to maintain personal hygiene, before every patient contact, after body substance exposure and after removing gloves. Hands were cleaned by using facilities involving water and a soap/non-medicated soap or antiseptic,hands were washed for at least 15 seconds, paying attention to all areas of the hands then they were rinsed under running water.

- Masks: They were fitted as per manufacturers' instructions, were changed if became wet from talking, coughing and exhalation.

- Disposable gloves: They were removed after examination of each patient.

- Clinical wastes: Mirrors and probes were placed in appropriate leak-resistant bags and then placed in the yellow containers bearing the international black biohazard symbol and clearly marked medical waste.
Assessment of zerostomia, periodontal disease and diabetic ketoacidosis attacks at last two years were recorded.

Statistical analysis: A statistical package program was used to evaluate the data obtained from the study. Descriptive statistical methods (frequency, proportion, mean, and standard deviation) were used in the evaluation of research data as well as the Kolmogorov-Smirnov distribution test for examining normal distribution. In comparing quantitative data, the unpaired samples $t$-test was used in intergroup comparison of parameters. Pearson's correlation coefficient was used to determine significant correlations between blood glucose levels, periodontal disese and DKA. The results were calculated at the $95 \%$ confidence interval, $p<0.05$ significance level and $p<0.01$ advanced significance level.

\section{Results}

91 uncontrolled Type 1 diabetic children participated in the present study. They were selected from El-Demerdash Hospital, Ain Shams University and the National Institute of Diabetes. The examined children included 50 boys and 41 girls. Data were collected by means of an open ended questionnaire covering patient records of weight and glycatedhaemoglobin $\mathrm{HbA}_{1 \mathrm{C}}$ for all the study participants. Clinical examination was then carried out to assess diabetic children periodontal disease experience and diabetic keto acidosis attacks in last two years.

No study participant left the research project for any reason. No side effects or complications were observed during the study. Baseline characteristics of the patients are shown in (Table 1). The study groupincluded 50 boys and 41 girls patients. The average age was $7.92 \pm 3.7$ years in boys and $7.58 \pm 2.96$ years in girls group. The average duration of diabetes was $5.41 \pm 3.13$ years in the boys and $4.88 \pm 2.29$ years in girls.

Table (1): Baseline characteristics of the patients.

\begin{tabular}{lllc}
\hline & \multicolumn{1}{c}{ Boys } & \multicolumn{1}{c}{ Girls } & $p$-value \\
\hline - Age (years, mean \pm SD) & $7.92 \pm 3.7$ & $7.58 \pm 2.96$ & .630 \\
- Duration of illness (years, & $5.41 \pm 3.13$ & $4.88 \pm 2.29$ & .365 \\
mean \pm SD) & & & \\
\hline
\end{tabular}

Data are presented as mean \pm SD.

No statistically significant difference was found between boys and girls in terms of age and duration of diabetes $(p>0.05)$, as shown in (Table 2$)$.

There was no statistically significant difference regarding periodontitis attacks and xerostomia 
attacks between boys and girls ( $p>0.05)$, as shown in (Table 2).

Table (2): Comparison between boys and girls regarding to periodontitis attacks and xerostomia.

\begin{tabular}{llll}
\hline & \multicolumn{1}{c}{ Boys } & \multicolumn{1}{c}{ Girls } & $p$-value \\
\hline Mild periodontitis & $6.61 \pm 2.73$ & $6.88 \pm 3.31$ & .674 \\
Moderate periodontitis & $1.90 \pm .94$ & $1.68 \pm .66$ & .199 \\
Severe periodontitis & $2.92 \pm 1.23$ & $2.9 \pm 1.57$ & .941 \\
Xerostomia & $4.57 \pm 1.77$ & $4.28 \pm 2.77$ & .541 \\
\hline
\end{tabular}

Data are presented as mean \pm SD.

There was no statistically significant difference regarding $\mathrm{HbA}_{1 \mathrm{C}}$, hypoglycemic and diabetic ketoacidosis attacks between boys and girls $(p>0.05)$, as shown in (Table 3).

Table (3): Comparison between boys and girls regarding to $\mathrm{HbA}_{1 \mathrm{C}}$, hypoglycemic and dka attacks.

\begin{tabular}{llll}
\hline & \multicolumn{1}{c}{ Boys } & \multicolumn{1}{c}{ Girls } & $p$-value \\
\hline HbA $_{1 C}$ & $9.66 \pm 1.41$ & $9.69 \pm 1.18$ & .906 \\
Hypoglycemic attack & $3.24 \pm 1.6$ & $3.2 \pm 1.4$ & .912 \\
DKA & $9.66 \pm 1.26$ & $9.69 \pm .75$ & .366 \\
\hline
\end{tabular}

Data are presented as mean \pm SD.

There was positive direct correlation between $\mathrm{HbA}_{1 \mathrm{C}}$ with both hypoglycemic and diabetic ketoacidosis attacks with $(p=.003 * *, .015 *)$ respectively, as shown in (Table 4).

Table (4): Correlation between hypoglycemic, diabetic ketoacidosis attacks and $\mathrm{HbA}_{1 \mathrm{C}}$.

\begin{tabular}{lcc}
\hline & $r$ & $p$-value \\
\hline Xerostomia vs. HbA $1 \mathrm{C}$ & -.091 & .392 \\
HbA 1C vs. hypoglycemic attack & $.293^{* *}$ & .003 \\
HbA 1C vs. DKA & $.244^{*}$ & .015 \\
\hline
\end{tabular}

Data are presented as mean \pm SD.

There was positive direct correlation between periodontitisand xerostomia with $(p=.000 * *)$, as shown in (Table 5).

Table (5): Correlation between periodontitis and xerostomia.

\begin{tabular}{lcc}
\hline & $r$ & $p$-value \\
\hline Xerostomia vs. mild periodontitis & $.729 * *$ & .000 \\
Xerostomia vs. mod periodontitis & $.520^{* *}$ & .000 \\
Xerostomia vs. severe periodontitis & $.544 * *$ & .000 \\
\hline Data are presented as mean + SD & &
\end{tabular}

Data are presented as mean \pm SD.

There was positive direct correlation between moderate, severe periodontitis and dka with $(p=$ $\left..000^{* *}\right)$ respectively, while there was no correlation between mild periodontitis and dka with $(p=.189)$ as shown in (Table 6).
Table (6): Correlation between periodontitis and DKA.

\begin{tabular}{lcc}
\hline & $r$ & $p$-value \\
\hline Dka vs. mild periodontitis & -.139 & .189 \\
Dka vs. mod periodontitis & $.387^{* *}$ & .000 \\
Dka vs. severe periodontitis & $.433^{* *}$ & .000 \\
\hline
\end{tabular}

Data are presented as mean $\pm \mathrm{SD}$

There was positive direct correlation between moderate, severe periodontitis and duration of diabetes mellites with $\left(p=.017 *, .003^{* *}\right)$ respectively, while there was no correlation between mild periodontitis and duration of diabetes mellites with $(p=.484)$ as shown in (Table 7).

Table (7): Correlation between periodontitis and diabetes mellites.

\begin{tabular}{lcc}
\hline & $r$ & $p$-value \\
\hline Duration vs. mild periodontitis & -.074 & .484 \\
Duration vs. mod periodontitis & $.250^{*}$ & .017 \\
Duration vs. severe periodontitis & $.305^{* *}$ & .003 \\
\hline
\end{tabular}

\section{Discussion}

Type 1 (insulin-dependent) diabetes mellitus (T1DM) is considered an endocrine metabolic syndrome of both childhood and adolescence, which is documented to be increased in a lot of countries all over the world. Diabetes mellitus is characterized by a cardinal biochemical feature which is hyperglycemia and with other important consequences for physical and emotional development [8]

Elevated blood glucose levels pathological mechanisms are due to the activation of the sorbitol pathway, Advanced Glycation End-products (AGEs) formation, the oxidative stress damaging effect and changes of lipid metabolism. These mechanisms have been accompanied with variable classical clinical complications of diabetes mellitus such as microvascular retinopathy, nephropathy, neuropathy, macrovascular disease and delayed wound healing and also periodontal disease [1]

Type 1 diabetic children are usually followingsucrose-restricted diets restrictingfoods rich in carbohydrates as a part of their life-long treatment decreasingprevalence of caries diabetic patients have lower, this was explained by the that is [9].

The risk of periodontitis is increased and reported to be dependent on the glycaemic control level of diabetes, periodontitis as risk for diabetes is shown to have little effect in Controlled diabetes with $\mathrm{HbA}_{1 \mathrm{c}}$ level of around $7 \%(53 \mathrm{mmol} / \mathrm{mol})$ or 
lower there appears to be of diabetes on for with increased risk whenglycaemic control deteriorates $[10,11]$

There are many mechanisms that explain the relation between diabetes and periodontitis which are not completely understood but include inflammation, immune functioning, neutrophil activity, and cytokine biology [12].

Systemic markers of inflammation are markedly elevated in both type 1 and type 2 diabetes [13]

Many oral manifestations and complications are associated with DM including dry mouth (xerostomia), tooth decay (including root caries), periapical lesions, gingivitis, periodontal disease, oral candidiasis, burning mouth (especially glossodynia), altered taste, geographic tongue, coated and fissured tongue, Oral Lichen Planus (OLP), recurrent aphthous stomatitis, increased tendency to infections, and wound healing deficiency $[\mathbf{1 4 , 1 5}$.

The severity of diabetic complications is directly proportional to both the duration and degree of hyperglycemia [16].

Diabetic patients with Periodontal disease has been reported to have higher levels of inflammatory mediators such as interleukin-1 $\beta$ (IL-1 0 ) and tumour necrosis factor-a (TNF- $(\mathrm{x})[\mathbf{1 7 , 1 8}]$.

Accumulation of reactive oxygen species, oxidative stress, and interactions between Advanced Glycation End products (AGEs) in the periodontal tissues and their receptor areall considered contributing factors that increase inflammation in the periodontal tissues in individuals with diabetes that can be considered another explaination of the link between diabetes and periodontitis [12]

Periodontal disease was reported to have a negative impact of on diabetes as, it was documented that severe periodontitis was associated with increased risk of poor glycaemic control $\left(\mathrm{HbA}_{1}\right.$ 。 $>9.0 \%, 75 \mathrm{mmol} / \mathrm{mol}$ ) may be compromising diabetes control with minimum of two years followup later [19].

Increased prevalence of diabetes complications, such as cardiovascular complications, retinopathy, neuropathy and proteinuria have been reported in patients with advanced periodontitis. Patients with type 2 diabetes who have moderate periodontitis, severe periodontitis, or who were edentulous were reported to have higher incidences of macroalbuminuria by $2.0,2.1$ and 2.6 times, respectively, compared to those with no/mild periodontitis [8] .
$\mathrm{HbA}_{1 \mathrm{c}}$ is reported to be decreased by $0.4 \%$ periodontal treatment $[\mathbf{2 0 , 2 1 ]}$

Also, similarly identified reduction of $\mathrm{HbA}_{1 \mathrm{c}}$ levels of approximately $0.4 \%$ was reported following non-surgical periodontal therapy [22] .

$\mathrm{HbA}_{1 \mathrm{c}}$ improvement is noted to have very significant clinical impacts as, every $1 \%$ reduction in $\mathrm{HbA}_{1 \mathrm{c}}$ is associated with a measurably reduced risk for diabetes complications [23].

\section{Conclusion:}

This study demonstrated that there was a significant link between the Periodontitis and diabetes. So, periodontal treatment is considered a relatively straightforward clinical intervention which doesn't have unwanted adverse effects and also may be associated with additional medications taken as part of diabetes treatment.

\section{Acknowledgment:}

Authors express appreciation to all patients participated in the study.

\section{References}

1- DAS M., UPADHYAYA V., RAMACHANDRA S.S. and JITHENDRA K.D.: Periodontal treatment needs in diabetic and non-diabetic individuals: A case-control study. Indian J. Dent. Res., 22 (2): 291-4, 2011.

2- ADA: Standards of medical care in diabetes-2010. Diabetes Care; 33 (Suppl. 1): S11-S61, 2010.

3- SHIP J.A.: Diabetes and oral health: An overview. JADA; 134 (suppl.): 4S-10S, 2003.

4- TWETMAN S., JOHANSSON I., BIRKHED D. and NEDERFORS T.: Garies: Incidence of caries in young type 1 diabetes mellitus patients in relation to metabolic control and caries associated risk factors. Garies Res., 36: 31-5, 2002.

5- LALLA E., KAPLAN S., CHANG S.M., ROTH G.A., CELENTI R., HINCKLEY K., GREENBERG E. and PAPAPANOU P.N.: Periodontal infection profiles in type 1 diabetes. J. Clin. Periodontol., 33 (12): 855-62, 2006.

6- LALLA E., CHENG B., LAL S., KAPLAN S., SOFTNESS B., GREENBERG E., GOLAND R.S. and LAMSTER I.B.: Diabetes mellitus promotes periodontal destruction in children. J. Clin. Periodontol., 34 (4): 294-8, 2007.

7- TAYLOR G.W., MANZ M.C. and BORGNAKKE W.S.: Diabetes; periodontal diseases; dental caries; and tooth loss: A review of the literature. Compend. Contin. Educ. Dent., 25 (3): 179-92, 2008

8- ROHANI B.: Oral manifestations in patients with diabetes mellitus. World J. Diabetes. Sep. 15, 10 (9): 485-9, 2019.

9- LAMSTER I.B., KUNZEL C. and LALLA E.: Management of the patient who smokes and the diabetic patient in the dental office. J. Periodontol., 77 (3): 331-40, 2008.

10- MEALEY B.L. and OCAMPO G.L.: Diabetes mellitus and periodontal disease. Periodontol., 44: 127-53, 2007. 
11- TSAI C., HAYES C. and TAYLOR G.W.: Glycaemic control of type 2 diabetes and severe periodontal disease in the US adult population. Community Dent. Oral Epidemiol., 30: 182-92, 2002.

12- TAYLOR J.J., PRESHAW P.M. and LALLA E.: A review of the evidence for pathogenic mechanisms that may link periodontitis and diabetes. J. Clin. Periodontol., 40 (Suppl 14): S113-134, 2013.

13- TAYLOR P., ALJADA A. and BANDYOPADHYAY A.: Inflammation: The link between insulin resistance, obesity and diabetes. Trends Immunol., 25: 4-7, 2004.

14- CICMIL S., MLADENOVIC' I., KRUNIC' J., IVANOVIC' D. and STOJANOVIC' N.: Oral Alterations in Diabetes Mellitus. Balk J. Dent. Med., 22: 7-14, 2018.

15- KHAN T.: Oral manifestations and complications of diabetes mellitus: A review. Int. J. Med. Health Res., 4: 50-2, 2018.

16- MAURI-OBRADORS E., ESTRUGO-DEVESA A., JANÉ-SALAS E., VIÑAS M. and LÓPEZ-LÓPEZ J.: Oral manifestations of Diabetes Mellitus. A systematic review. Med. Oral Patol. Oral. Cir. Bucal., 22: e586-e594, 2017.

17- ENGEBRETSON S.P., HEY-HADAVI J., EHRHARDT F.J., et al.: Gingival crevicular fluid levels of interleukin $1 \beta$ and glycaemic control in patients with chronic periodontitis and type 2 diabetes. J. Periodontol., 75: 1203-8, 2004.
18- ENGEBRETSON S., CHERTOG R., NICHOLS A., HEYHADAVI J., CELENTI R. and GRBIC J.: Plasma levels of tumour necrosis factor-alpha in patients with chronic periodontitis and type 2 diabetes. J. Clin. Periodontol., 34: 18-24, 2007.

19-TAYLOR G.W., BURT B.A., BECKER M.P., et al.: Severe periodontitis and risk for poor glycaemic control in patients with non-insulin-dependent diabetes mellitus. J. Periodontol., 67: 1085-93, 1996.

20- DARRE L., VERGNES J.N., GOURDY P. and SIXOU M.: Efficacyof periodontal treatment on glycaemic control in diabetic patients: A meta-analysis of interventional studies. Diabetes Metab., 34: 497-506, 2008.

21-TEEUW W.J., GERDES V.E.A. and LOOS B.G.: Effect of periodontal treatment on glycaemic control of diabetic patients: A systematic review and meta-analysis. Diabetes Care, 33: 421-7, 2010.

22- SIMPSON T.C., NEEDLEMAN I., WILD S.H., MOLES D.R. and MILLS E.J.: Treatment of periodontal disease for glycaemic control in people with diabetes. Cochrane Database Syst. Rev., CD004714, 2010.

23- STRATTON I.M., ADLER A.I., NEIL H.A., et al.: Association of glycaemia with macrovascular and microvascular complications of type 2 diabetes (UKPDS 35): Prospective observational study. BMJ, 321: 405-12, 2000. 


\section{معدل إنتشار آمراض اللثة فى مجموعة من الآطفال المصريين

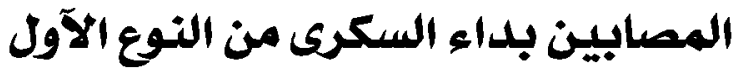

داء السكرى (DM) هو متلازمة آيضية خطيرة مع نوعين آساسيين يؤديان إلى التمثيل الغذائى غير الطبيعى للدهون والكريوهيدرات والبروتين.

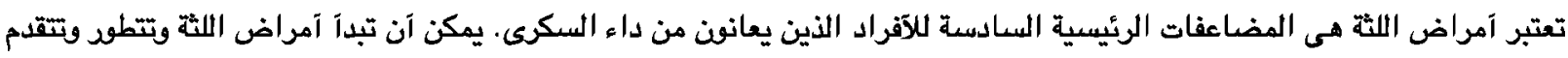
بسبب الإختلالات الآيضية فى الآنسجة التى تقلل من مقاومة مرضى السكرى اللعدىى.

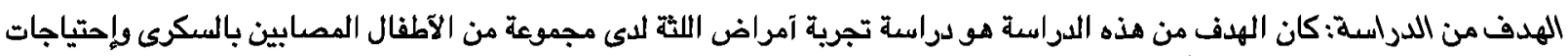

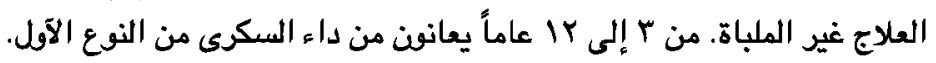

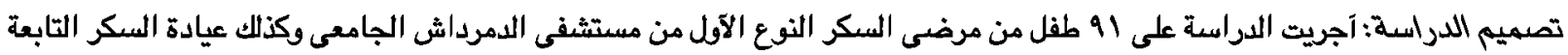

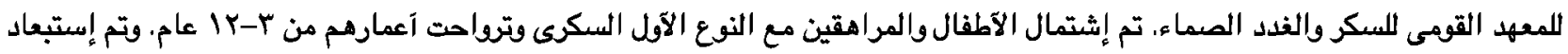
الآطفال يعانقن من مرض مزمن آو عدوى مزمنة الآطفال مع النوع الثانى السكرى.

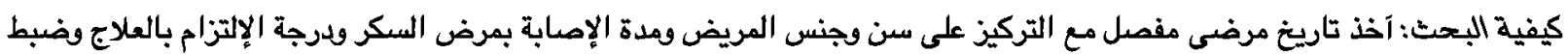
السكر ووجود آى شكوى آو تاريخ مرض تدل على حدوث مضاعفات. تم عمل فحص دقيق مع التركيز على وذن المريض وطوله وعلامات ترجح حدوث آى مضاعفات.

إشتملت الدراسة على قياس (مستوى السكر بالدم - مستوى الهيموجلوبين السكرى - معدل الإصابة بآمراض اللثة بدرجاتها الثالاث آى جفاف الحلق آو حدوث غييوبة سكرية خلال آخر عامين).

نتائج البحث: هناك علاقة طردية إيجابية بين مستويات السكر فى الدم ومعدلات الإصابة بآمراض اللثة بدرجاتها الثالاث آو جفاف الحلق أو حلوث غيبوبة سكرية خلال آخر عامين.

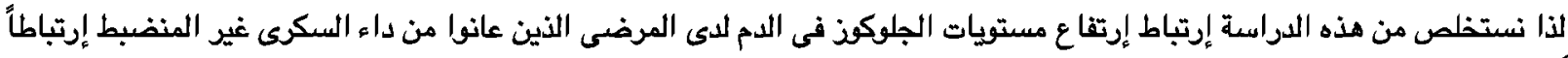

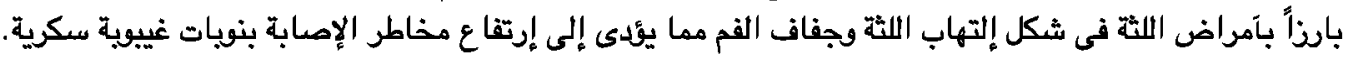

